\title{
ANALISIS FAKTOR EKONOMI VOLUME EKSPOR KAKAO MENTAH INDONESIA
}

\author{
Muhammad Arief Budiman
}

Departemen Sosial Ekonomi, Fakultas Pertanian Universitas Padjadjaran

Email:muhammad@unpad.ac.id

\begin{abstract}
ABSTRAK
Kakao mentah di Indonesia termasuk dalam komoditas unggulan yang memberikan kontribusi dalam upaya peningkatan devisa Indonesia melalui. Tulisan ini bertujuan untuk menganalisa signifikansi besaran nilai volume ekspor kakao mentah yang dipengaruhi oleh faktor-faktor ekonomi. Penelitian ini menggunakan desain kuantitatif dan studi litelatur menggunakan data sekunder, sampel data yang digunakan bersifat kurun waktu selama 30 tahun hingga tahun 2013. Metodologi penelitian ini menggunakan model ekonometrika dengan teknik analisis regresi berganda dan metode kuadrat terkecil atau ordinary least square (OLS). Hasil penelitian menunjukan bahwa secara partial Variabel Jumlah Produksi Kakao Indonesia, Nilai Tukar Rupiah, Harga Domestik Biji Kakao Indonesia memiliki pengaruh yang signifikan dan pajak ekspor secara partial memiliki pengaruh yang tidak signifikan terhadap perkembangan volume ekspor biji kakao Indonesia. Sedangkan secara simultan Variabel Jumlah Produksi Kakao Indonesia, Nilai Tukar Rupiah, Harga Domestik Biji Kakao Indonesia dan Pajak Eksport memiliki pengaruh yang signifikan terhadap perkembangan volume ekspor biji kakao Indonesia.
\end{abstract}

Kata kunci : volume ekspor biji kakao Indonesia, harga domestik, pajak ekspor, nilai tukar rupiah

\begin{abstract}
Indonesian raw cocoa is one of commodities that has important roles on Indonesian export, especially for economic growth on GDP. Indonesian cocoa beans included in the priority which has a very important role in export activities including in Indonesia as one of the primary commodity which would contribute to an increase in foreign exchange for Indonesia. This paper aims to identify how big the influence of the total production of Indonesian cocoa beans, exchange rate, cocoa beans price and the export tax to the amount of Indonesia's exports of cocoa both simultaneously and to identify which are the most influential factor. This study design is a quantitative research. Data were gained through desk study with time series data of 30 years. This research used econometrics to reflect the outcome of the discussions to be expressed in numbers by using multiple regression analysis and ordinary least square (OLS). The results show that the simultaneous variable the production of Indonesian cocoa, Exchange Rate, Domestic Prices of Indonesian cocoa beans and Export Tax has a significant influence on the development of Indonesian cocoa beans exports volume. A partial variable the production of Indonesian cocoa, Exchange Rate, Domestic Prices of Indonesian cocoa beans has a significant influence and the partial export tax has no significant effect on the development of Indonesian cocoa exports volume.
\end{abstract}

Keywords: Indonesian cocoa beans volume exports, domestic prices, export taxes

\section{PENDAHULUAN}

Pertukaran barang skala internasional merupakan yang biasa dilakukan antar negara di dunia (ekspor dan impor). Pada hakikatnya perdagangan luar negeri timbul karena tidak ada satu negara pun yang dapat menghasilkan semua barang dan jasa untuk memenuhi kebutuhan seluruh penduduk. Sektor pertanian di Indonesia menghasilkan berbagai jenis komoditas salah satunya adalah subsektor perkebunan yang merupakan salah satu subsektor pertanian yang penting bagi perdagangan internasional. Subsektor ini dominan kontribusinya terhadap nilai ekspor dalam neraca perdagangan Indonesia (ekspor impor) setelah subsektor perikanan dan tanaman pangan. (Departemen Pertanian, 2012).

Biji kakao Indonesia sudah termasuk dalam komoditas andalan yang memiliki peranan yang cukup penting dalam kegiatan ekspor Indonesia karena temasuk kedalam salah satu 
komoditi unggulan yang memberikan kontribusi dalam upaya peningkatan devisa Indonesia. Dari segi kualitas, kakao Indonesia tidak kalah dengan kakao dunia dimana bila dilakukan fermentasi dengan baik dapat mencapai cita rasa setara dengan kakao yang berasal dari Ghana dan kakao Indonesia mempunyai kelebihan yaitu tidak mudah meleleh sehingga cocok bila dipakai untuk blending. Sejalan dengan keunggulan tersebut, perkebunan kakao Indonesia mengalami perkembangan pesat sejak awal tahun 1980-an dan pada tahun 2002 serta peluang pasar kakao Indonesia cukup terbuka baik ekspor maupun kebutuhan dalam negeri. Indonesia memiliki potensi untuk mejadi negara produsen utama kakao dunia dan menjadi negara pengekspor terbesar biji kakao, namun dengan permasalahan produksi kakao yang terus menurun setiap tahunnya serta dampak diberlakukannya pajak ekspor terhadap biji kakao menyababkan volume ekspor biji kakao Indonesia terus menurun maka dari itu peneliti akan menganalisis beberapa faktor yang mempengaruhi volume ekspor biji kakao Indonesia.

Penelitian ini bertujuan untuk mencari berapa besaran nilai faktor jumlah produksi kakao Indonesia, nilai tukar rupiah, pajak eksport dan harga biji kakao Indonesia mempengaruhi volume ekspor biji kakao Indonesia baik secara simultan maupun partial? Serta faktor manakah yang paling berperan dalam perkembangan ekspor biji kakao diantara jumlah produksi biji kakao Indonesia, nilai tukar rupiah, pajak ekspor dan harga biji kakao Indonesia baik secara simultan dan partial?

\section{KERANGKA KONSEP}

Kebijakan Ekspor Mengenai Kakao.

Kebijakan pajak ekspor yang ditetapkan oleh pemerintah akan mempengaruhi laju volume ekspor kakao Indonesia. Sedangkan jika produksi kakao tetap maka akan mempengaruhi jumlah ketersediaan domestik. Apabila volume ekspor naik maka ketersediaan domestik akan berkurang, begitu pula apabila ketersediaan domestik lebih besar maka volume ekpsor akan kecil. Pada akhirnya ketersediaan domestik kakao Indonesia yang akan mempengaruhi harga kakao di pasar domestik. Dampak dari kebijakan pajak ekspor yang telah dikeluarkan pemerintah akan memberikan pengaruh positif dan negatif.

Teori Klasik (Merkantilisme). Sesuai dengan kenyataan Indonesia, Dengan kata lain volume ekspor biji kakao Indonesia lebih besar dibandingkan impor karena Indonesia sebagai negara produsen terbesar ke tiga biji kakao dan tidak mengimpor biji kakao dari luar negri hal ini sesuai dengan teori merkantilisme.

Teori Keunggulan Absolut (Absolute Advantage). Indonesia memiliki keunggulan absolut dalam memproduksi biji kakao di bandingkan dengan Malaysia karena Indonesia memiliki lahan yang cukup luas dengan jumlah produksi ke tiga terbesar di dunia setelah Pantai Gading dan Ghana, dengan demikian Indonesia mengekspor biji kakao ke Malaysia dan Indonesia impor kebutuhan lainnya yang tidak bisa di produksi Indonesia seperti mesinmesin industri dari Malaysia.

\section{Teori Keunggulan Komparatif}

(Comparative Advantage). Pada kenyataannya Indonesia memiliki keunggulan mutlak dalam memproduksi biji kakao di banding dengan Malaysia namun di sisi lain Malaysia memiliki keunggulan dalam mengolah biji kakao menjadi produk olahan. Dengan demikian Indonesia mengekspor biji kakao mentah ke Malaysia dan Indonesia impor produk olahan kakao dari Malaysia guna memenuhi kebutuhan industri dalam negri. Dengan demikian maka akan tetap terjadi perdagangan Internasional.

\section{Alur Perdagangan Biji Kakao}

Indonesia. Rantai pemasaran biji kakao dari petani berbeda-beda untuk setiap daerah. Namun, sebagian besar petani kakao di Indonesia menjual melalui pengumpul atau tengkulak ada juga yang langsung menjual ke pasar lokal, ataupun perusahaan. Dari pasar lokal biji kakao kering di distribusikan ke eksportir lokal maupun ke eksportir multinasional. di sini eksportir lokal ada yang menjual ke eksportir multinasional lalu dari eksportir nasional maupun lokal dieksport ke luar negri. Perusahaan yang membeli biji kakao dari petani lalu di olah menjadi bahan setengah jadi yang masih berupa biji kakao, biji kakao langsung di eksport ke luar negri oleh perusahaan. Bagan alur perdagangan biji kakao dari perkebunan rakyat atau dari petani ke eksportir bisa dilihat pada gambar berikut. 


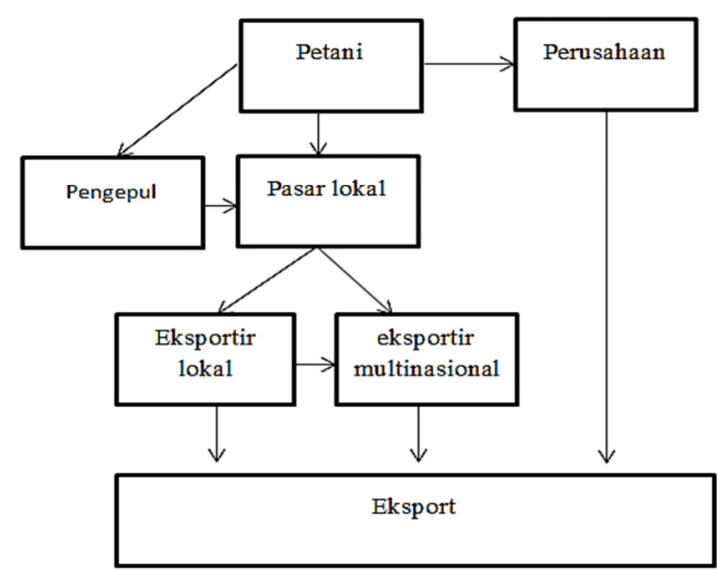

Gambar 2. Alur perdagangan biji kakao Indonesia Sumber : Dinas Perindustrian dan Perdagangan Jawa Barat

\section{METODE PENELITIAN}

Objek dan Tempat Penelitian. Objek dari penelitian yang akan di teliti adalah beberapa faktor yang mempengaruhi volume ekspor biji kakao Indonesia yaitu jumlah produksi kakao Indonesia, nilai tukar Rupiah terhadap Dollar Amerika Serikat, pajak ekspor dan harga domestik biji kakao Indonesia. Penelitian ini mengambil data di Indonesia dengang ruang lingkup penelitian yaitu "Beberapa Faktor yang Mempengaruhi Ekspor Biji Kakao Indonesia Periode tahun 19842013". Kegiatan penelitian yang akan di lakukan yaitu perumusan masalah, rencana penelitian, pengumpulan data dari berbagai sumber terkait.

Desain Dan Teknik Penelitian. Desain penelitian yang di gunakan adalah dengan desain kuantitatif sifatnya suatu kasus dengan teknik penelitian studi kepustakaan (Deks Study) menggunakan data sekunder sampel data yang digunakan bersifat kurun waktu (time series) data yang di perlukan yaitu jumlah produksi biji kakao indonesia, nilai tukar Rupiah terhadap Dollar Amerika Serikat, pajak ekspor dan harga domestik biji kakao Indonesia yang merupakan data tahunan selama 30 tahun dari tahun 1984 sampai tahun 2013. Data yang diperoleh tersebut akan di regres menggunakan beberapa model untuk mengetahui faktor mana yang berpengaruh terhadap volume ekspor biji kakao Indonesia baik secara simultan maupun partial. model rumusan variabel yang akan di gunakan di formulasikan dalam persamaan sebagai berikut

$$
\hat{\mathrm{y}}=\beta_{0}+\beta_{1} X_{1}+\beta_{2} X_{2}+\beta_{3} X_{3}+\beta_{4} X_{4}
$$

Keterangan :

$\hat{y} \quad$ : Volume Ekspor Biji Kakao (VEX)

$X_{1}$ : Jumlah Produksi Kakao indonesia (JPKI)

$X_{2} \quad$ : Nilai Tukar Rupiah (NTR)

$X_{3}$ : Harga Domestik Biji Kakao Indonesia (HDBKI)

$X_{4}$ : Pajak Eksport (PE)

: Konstanta

\section{Rancangan Analisis Faktor}

Model ekonometrika digunakan untuk mencerminkan hasil dari pembahasan yang akan dinyatakan dengan angka, teknik analisis yang di gunakan dalam penelitian ini adalah analisis regresi berganda dan metode yang di gunakan adalah metode kuadrat terkecil atau method of ordinary least square (OLS) yang merupakan metode yang digunakan untuk mengkoreksi persamaan regesi diantara variabel-variabelnya. Operasional pengolahan data dilakukan dengan software SPSS (Statistik Package For Social Science) versi 20, metode OLS memiliki beberapa keunggulan yaitu secara teknis mudah dalam menarik interpretasi, perhitungan dan penaksiran BLUE (Best Linear Unbiased Estimator) (Gujarati, 2012).

Selain itu dalam proses menganalisis data digunakan uji statistik dan uji asumsi klasik sebagai alat bantu untuk mengestimasi volume ekspor biji kakao (dependen variable) dan faktor-faktor yang di perkirakan mempengaruhinya (independen variable). Uji ststistik meliputi uji koefisien determinasi ujiF dan Uji-T, sedangkan uji asumsi klasik meliputi uji normalitsa, uji multikolienaritas, uji autokorelasi dan uji Heterokedastisitas.

\section{HASIL DAN PEMBAHASAN}

Tantangan Dalam Ekspor Biji Kakao

Indonesia. Produksi biji kakao di Indonesia masih mengalami beberapa permasalahan yang menghambat perkembangan ekspor kakao. Produksi biji kakao Indonesia untuk diekspor ke pasar internasional belum mampu mengimbangi produksi biji kakao Pantai Gading dan Ghana. Hal tersebut disebabkan oleh rendahnya mutu kualitas biji kakao. Selain itu, fermentasi biji kakao yang belum sempurna dan mengalami kerusakan pada saat pengiriman sehingga harga biji kakao Indonesia mengalami penurunan pada pasar internasional. Kualitas biji kakao yang diekspor oleh Indonesia dikenal rendah. Selama ini, biji kakao Indonesia merupakan 
batas standar mutu ekspor-impor biji kakao. Bahkan di Amerika Serikat, biji kakao Indonesia selalu mendapatkan penahanan (automatic detention) karena sering ditemukan jamur, kotoran, serangga dan benda-benda asing lainnya (BBPPTP Surabaya 2015).

\section{Hasil Analisa Data}

Model Yang Digunakan

Model yang dirumuskan yaitu model regresi linier berganda dengan metode Ordinary Least Square (OLS) dan diperoleh model regresi sebagai berikut:

$\hat{Y}=35,188+0,518 X_{1}+19,215 X_{2}+0,001$ $\mathrm{X}_{3}-0,018 \mathrm{X}_{4}+\mathrm{e}$

Berdasarkan model regresi yang dihasilkan bisa dijelaskan hubungan antara variabel $\mathrm{X}$ dan $\mathrm{Y}$ secara spesisfik sebagai berikut:

1. $\mathrm{X}_{1=}$ setiap kenaikan seribu ton produksi kakao maka volume ekspor biji kakao bertambah 0,518 ribu ton atau 518 ton.

2. $\mathrm{X}_{2}$ = setiap kenaikan seribu mata uang Rupiah terhadap Dolar atau terdepresiansinya Rupiah terhadap Dolar maka volume ekspor biji kakao indonesia akan bertambah sebesar 19,215 ribu ton atau 19.215 ton.

3. $\mathrm{X}_{3}=$ setiap kenaikan seribu rupiah pajak ekspor maka akan menyebabkan meningkatnya volume ekspor biji kakao sebesar 0.001 ribu ton atau 1 ton.

4. $\mathrm{X}_{4}=$ setiap kenaikan seribu rupiah harga biji kakao dalam negri maka akan menyebabkan menurunnya volume ekspor biji kakao sebesar 0,018 ribu ton atau 18 ton.

\section{Analisi Uji Statistik}

Uji Koefisien Determinan $\left(R^{2}\right)$ Hasil

Perhitungan $R$ dan Dw

Model Summary ${ }^{\mathrm{b}}$

\begin{tabular}{|l|l|l|l|l|l|}
\hline Model & $\mathrm{R}$ & $\begin{array}{l}\mathrm{R} \\
\text { Square }\end{array}$ & $\begin{array}{l}\text { Adjusted } \\
\mathrm{R} \\
\text { Square }\end{array}$ & $\begin{array}{l}\text { Std. Error } \\
\text { of the } \\
\text { Estimate }\end{array}$ & $\begin{array}{l}\text { Durbin- } \\
\text { Watson }\end{array}$ \\
\hline 1 &, $919^{\mathrm{a}}$ &, 844 &, 819 & 57,207256 & 1,827 \\
\hline
\end{tabular}

Sumber : hasil perhitungan data menggunakan SPSS 20.

Dari hasil regresi data dengan menggunakan SPSS di peroleh nilai koefisien $\mathrm{R}^{2}$ sebesar 0,844 . Hal ini menunjukan bahwa sebesar $84,4 \%$ volume ekspor biji kakao di pengaruhi oleh variabel-variabel bebas yang terdapat dalam persamaan, yaitu produksi kakao domestik, nilai tukar rupiah, pajak eksport dan harga domestik. Sisanya yaitu sebesar $15,6 \%$ di pengaruhi oleh variabel- variabel lain yang tidak termasuk dalam persamaan.

Uji F Statistik

Taraf signifikansi yang di gunakan adalah $5 \%$ atau $\alpha=0,05$. Hasil perhitungan dapat di lihat pada tabel berikut.

Hasil Perhitungan Uji F Statistik

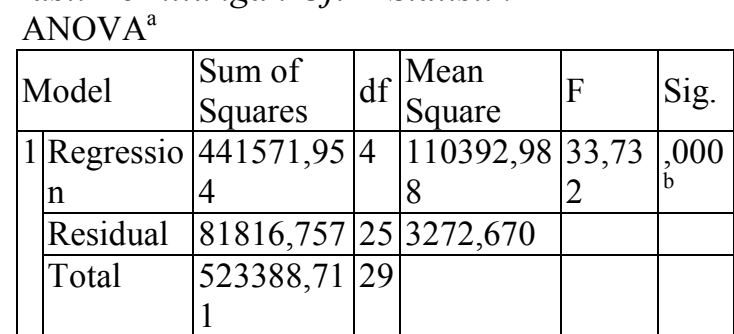

Sumber : hasil perhitungan data menggunakan SPSS 20.

Disimpulkan bahwa produksi kakao domestik, nilai tukar rupiah, pajak eksport dan harga domestik secara simultan mempengaruhi volume ekspor biji kakao Indonesia. Hal ini mengindikasikan bahwa model dianggap mampu merepresentasikan volume ekspor biji kakao Indonesia.

\section{Uji T Statistik (Nilai T Hitung)}

Faktor pajak ekspor secara partial berpengaruh signifikan dengan nilai negatif terhadap volume ekspor biji kakao Indonesia dengan artian pajak ekspor memiliki pengaruh yang negatif terhadap perkembangan volume ekspor biji kakao Indonesia.

\section{Analisis Uji Asumsi Klasik}

Uji Normalitas

Dari hasil uji normalitas dengan

Metode Kolmogorov Smirnov dan diagram scater plot dapat disimpulakan nilai residula sudah terdistribusi dengan normal

\section{Uji Autokorelasi}

\section{Uji Multikolinieritas}

Dari nilai VIF setiap masing-masing variabel $\mathrm{X} 1, \mathrm{X} 2, \mathrm{X} 3$ dan $\mathrm{X} 4$ nilai variabelnya tidak lebih dari 10 atau lebih kecil dari 10 yang berarti sehingga tidak terjadi masalah Multikolinieritas.

\section{Uji Heterokedastisitas}

Uji heteroskedastisitas digunakan untuk mengetahui ada atau tidaknya penyimpangan asumsi klasik heteroskedastisitas yaitu adanya ketidaksamaan varian dari residual untuk semua pengamatan pada model regresi.

Berdasarkan Uji Glejser juga diperoleh nilai signifikansi dari masing-masing variabel $\mathrm{X}$ bernilai lebih dari 0,05 . Hal ini juga menunjukan bahwa model regresi tidak meiliki gejala heterokedastisitas. 
Analisis Terhadap Hasil Pengujian. Berdasarkan pengujian menggunakan uji simultan dan uji parsial diperoleh hasil uji simultan semua variabel bebas berpengaruh signifikan terhadap jumlah volume ekspor biji kakao Indonesia. Sedangkan pada uji parsial menunjukan bahwa variabel bebas yang memiliki pengaruh signifikan terhadap volume ekspor biji kakao Indonesia.

Berdasarkan uji simultan Dari hasil regresi didapat $\mathrm{F}$ hitung sebesar 33,732 dengan nilai probabilitas 0,000 . Kemudian untuk Nilai $\mathrm{f}$ kritis atau $\mathrm{f}$ tabel sebesar 2,98. Karena nilai $\mathrm{f}$ hitung lebih besar daripada $f$ tabel berarti Dari hasil analisis ini bisa disimpulkan bahwa produksi kakao domestik, nilai tukar rupiah, pajak eksport dan harga domestik secara simultan mempengaruhi volume ekspor biji kakao Indonesia.

Berdasarkan uji partial untuk variabel produksi kakao domestik didapat $t$ hitung sebesar 4,842 dan nilai signifikannya adalah 0,000 serta nilai $t$ tabel sebesar 2,055. Maka $t$ hitung lebih besar dari t tabel serta nilai signifikannya tidak lebih dari 0,05 ( $\mathrm{t}$ hitung $>\mathrm{t}$ tabel dan $0,000<0,05)$ sehingga secara partial faktor produksi kakao domestik berpengaruh signifikan dengan nilai yang positif terhadap volume ekspor biji kakao Indonesia.

Uji t parsial untuk variabel nilai tukar rupiah didapat $\mathrm{t}$ hitung sebesar 2,416 dan nilai signifikan adalah 0,023 serta nilai $t$ tabel sebesar 2,055. Maka t hitung lebih besar dari $t$ tabel serta nilai signifikannya tidak lebih dari 0,05 (t hitung $>\mathrm{T}$ tabel dan $0,023<0,05$ ) sehingga faktor nilai tukar rupiah secara partial berpengaruh signifikan dengan nilai yang positif terhadap volume ekspor biji kakao indonesia

Uji t pada variabel pajak ekspor di dapat t hitung sebesar 1,116 dan nilai signifikannya adalah 0,255 serta nilai $t$ tabel sebesar 2,055. Maka t hitung lebih kecil dari $t$ tabel dan nilai signifikannya lebih besar dari 0,05 (t hitung $<\mathrm{t}$ tabel dan $0,255>0,05)$ sehingga faktor pajak ekspor secara partial tidak berpengaruh yang signifikan terhadap volume ekspor biji kakao Indonesia. Walaupun secara partial nilainya tidak signifikan akan tetapi pajak ekspor memiliki pengaruh yang positif terhadap volume ekspor biji kakao Indonesia walaupun pengaruhnya sangat kecil.

\begin{tabular}{lll}
\multicolumn{2}{l}{ Hasil Uji Simultan dan Partial } & \\
\hline Variabel Bebas & Uji F & Uji T \\
\hline X1 Produksi & & Signifikan \\
Kakao Indonesia & & \\
X2 Nilai Tukar & & Signifikan \\
Rupiah & Signifikan & Tidak \\
X3 Pajak & & Signifikan \\
Eksport & Signifikan \\
X4 Harga & & \\
Domestik & &
\end{tabular}

Pengaruh Jumlah Produksi Kakao Indonesia (X1) Terhadap Volume Ekspor Biji Kakao Indonesia. Dari hasil uji t atau uji parsial variabel produksi kakao indonesia memiliki pengaruh signifikan dengan nilai yang positif terhadap volume ekspor biji kakao Indonesia. hal ini sesuai dengan hipotesis penelitian. Produksi kakao domestik memiliki pengaruh terhadap volume ekspor biji kakao Indonesia karena semakin banyak indonesia memproduksi kakao maka peluang untuk menambah volume ekspor semakin banyak pula.

Produksi biji kakao Indonesia mampu meningkatkan volume ekspor biji kakao. Begitupun sebaliknya jika produksi terjadi penurunan maka volume ekspor biji kakao akan mengalami penurunan karena tidak ada barang yang ditawarkan kepada konsumen. Berdasarkan beberapa pertimbangan tersebut, produksi biji kakao Indonesia yang sesuai dengan syarat mutu akan mampu meningkatkan ekspor biji kakao ke luar negeri.

Pengaruh Nilai Tukar rupiah (X2)

Terhadap Volume Ekspor Biji Kakao Indonesia. Setiap kenaikan seribu mata uang Rupiah terhadap Dolar atau terdepresiansinya Rupiah terhadap Dolar maka volume ekspor biji kakao indonesia akan bertambah sebesar 19,215 ribu ton atau 19.215 ton. Dari hasil uji $t$ atau uji parsial variabel nilai tukar rupiah memiliki pengaruh signifikan terhadap volume ekspor biji kakao Indonesia, dan uji f atau uji simultan variabel nilai tukar rupiah memiliki pengaruh yang signifikan terhadap volume ekspor biji kakao Indonesia. hal ini sesuai dengan hipotesis penelitian.

\section{Pengaruh Pajak Ekspor (X3)}

Terhadap Volume Ekspor Biji Kakao Indonesia. Pajak ekspor akan berpengaruh terhadap harga di tingkat dunia dari komoditi biji kakao Indonesia. Dengan demikian, pajak ekspor sangat berhubungan dengan volume perdagangan suatu negara. Pada uji $t$ atau uji 
parsial variabel pajak ekspor tidak memiliki pengaruh signifikan terhadap volume ekspor biji kakao Indonesia, sedangkan pada uji f atau uji simultan variabel pajak ekspor memiliki pengaruh yang signifikan terhadap volume ekspor biji kakao Indonesia. hal ini sesuai dengan hipotesis penelitian dengan alasan.।

Pengaruh harga Domestik Biji Kakao Indonesia (X4) Terhadap Volume Ekspor Biji Kakao Indonesia. Dilihat dari model regresi yang dihasilkan, variabel harga domestik biji kakao Indonesia memiliki nilai yang negatif terhadap volume ekspor biji kakao Indonesia. hal ini sesuai dengan hipotesis penelitian.

\section{KESIMPULAN}

Berdasarkan hasil analisis data menggunakan model regresi linier berganda dan metode Ordinary Least Square dapat disimpulkan bahwa faktor produksi kakao Indonesia mampu menaikan volume ekspor biji kakao Indonesia sebesar 518 ton apabila produksi kakao dalam negri meningkat sebesar 1000 ton, faktor nilai tukar rupiah mampu menaikan volume ekspor biji kakao Indonesia sebesar 19.215 ton setiap terdepresiasinya nilai mata uang rupiah Rp.1000/\$, faktor pajak ekspor mampu menaikan volume ekspor sebesar 1 ton setiap kenaikan Rp.1000,- pajak ekspor dan faktor harga domestik akan meneurunkan volume ekspor biji kakao sebesar 18 ton setiap kenaikan Rp.1000,- harga domestik. Secara simultan variabel produksi kakao Indonesia, nilai tukar rupiah, pajak ekspor, harga domestik berpengaruh signifikan dan secara partial hanya variabel pajak ekspor yang tidak signifikan nilainya, akan tetapi tetap memiliki pengaruh terhadap perkembangan volume ekspor biji kakao Indonesia walaupun pengaruhnya sangat kecil. Faktor yang paling berperan dalam perkembangan volume ekspor biji kakao Indonesia dari yang terbesar sampai yang terkecil adalah Nilai Tukar Rupiah, Produksi Kakao Indonesia, Harga Domestik Biji Kakao dan Pajak ekspor.

\section{DAFTAR PUSTAKA}

Anni Rahimah, SAB, MAB. 2010. Administrasi Kepabean dan Ekspor Impor.Bisnis Internasional Universitas Brawijaya.
Agroforstry and forestry Sulawesi. 2013. Panduan Budidaya Kakao untuk petani kecil. Journal no 6.

Balittri .2012. Peningkatan Produksi dan Pengembangan Kakao (Theobroma cacao L.) di Indonesia. vol 3 (1).

Dinan Arya Putra. 2013. Analisis Faktor-faktor yang Mempengaruhi Ekspor Tembakau Indonesia ke Jerman. Universitas Negeri Semarang.

Abdoellah, S. 2009. Perkembangan Penelitian. Dalam "Paduan Lengkap Kakao" (Wahyudi et al., eds.). Penyebar Semangat. Jakarta.

Dewi Anggraini. 2006. Faktor-Faktor yang Mempengaruhi Permintaan Ekspor Kopi Indonesia dari Amerika Serikat. Tesis Magister Program Pascasarjana Ilmu Ekonomi dan Studi Pembangunan Universitas Diponegoro Semarang

Direktorat Jenderal Pengolahan dan Pemasaran Hasil Pertanian. 2014. Statistik Ekspor Impor Komoditas Pertanian Tahun 2001-2013. Jakarta: Kementerian Pertanian Republik Indonesia.

Drs. Halwani,M.A dan Dr, H. Prijono Tjiptoheridjanto. 1993. Perdagangan Internasional pendekatan Ekonomi Mikro dan Makro. Ghalia Indonesia.

Flora Felina Aditasari. (2011) Faktor-Faktor yang Mempengaruhi Eksport Karet Indonesia ke RRC (Republik Rakyat Cina) Tahun 1999-2009.Universitas Sebels msret Surakarta.

Gujarati, Damodar. 2009. Dasar-dasar Ekonometrika. Jakarta: Salemba Empat.

Hady, Hamid. 2001. Ekonomi Internasional: Teori dan Kebijakan Perdagangan Internasional. Jakarta: Ghalia Indonesia.

Won Koo. 2005. Internasional Trade And Agriculture. Vicotria: Blackwell Publishing.

Krugman, P.R. and M. Obstfeld; diterjemahkan Faisal H. Basri. 2003. Ekonomi Internasional: Teori dan Kebijakan. Jakarta: Raja Grafindo Persada.

Laporan Kementrian Keuangan. 2012. Peraturann Mentri Keuangan republik Indonesia, Penetapan Barang Ekspor Yang Di kenakan Tarif Keluar Dan Tarif Bea Keluar.

Lapoaran Kementerian Perdagangan Indonesia. Ekspor biji kakao Indonesia Berdasarkan Negara Tujuan 2013. 
Laporan Badan Perencanaan Pembangunan Nasional (BAPPENAS). 2013.

Perkembangan Perekonomian Indonesia Triwulan 1 tahun 2013.

Laporan Kementerian Perdagangan Indonesia. Perkembangan Ekspor Pertanian Indonesia Tahun 2004-2013.

Laporan Food Association Organization (FAO). Produksi biji kakao Dunia Tahun 2008-2013.

http://faostat3.fao.org/home/E di akses pada tanggal 22 februari 2013.

Laporan Food Association Organization (FAO). Volume ekspor biji kakao Indonesia tahun 1984-2013. http://faostat3.fao.org/home/E di akses pada tanggal 22 februari 2013.

Laporan Food Association Organization (FAO). Produksi biji kakao Indonesia Tahun 1984-2103.

http://faostat3.fao.org/home/E di akses pada tanggal 22 februari 2013.

Laporan Food Association Organization (FAO). Luas lahan perkebunan kakao tahun 1984-2013.

http://faostat3.fao.org/home/E di akses pada tanggal 22 februari 2013.

Laporan Kementerian Perdagangan Indonesia. Perkembengan Ekspor Migas dan Nonmigas Indonesia Tahun 2004-2013.

Rahardja, Pratama. Mandala Manurung. 2008. Pengantar Ilmu Ekonomi: Miroekonomi dan Makroekonomi. Jakarta: Lembaga Penerbit Fakultas Ekonomi Universitas Indonesia

Rubiyo dan Susanto. 2012. Peningkatan produksi dan pengembangan kakao indonesia. buletin RISTRI vol 3 (1) 2012.

Oktaviani R dan Novianti T. 2009. Teori Perdagangan Internasional dan Aplikasinya di Indonesia. Bogor: IPB Press.

Sugiyono. 2014. Metode Penelitian Kuantitatif dan Kualitatif. Bandung: Alfabeta.

Sadono Sukirno. 2011. Makro ekonomi Teori Pengantar. Jakarta: PT. Raja Grafindo Persada.

Tambunan, Tulus. 2005. Perdagangan Internasional dan Neraca Pembayaran: Teori dan Temuan Empiris. Jakarta: LP3S.

Tim Peneliti. 2014. Statistik Indonesia: Indonesia Dalam Angka 1996-2014. Jakarta: Badan Pusat Statisitk Indonesia.

Adera Verena. 2014. Analisis Faktor yang Mempengaruhi Ekspor Manggis Indonesia. Jatinangor: Fakultas Pertanian Universitas Padjadjaran.

Yustika, A., E. (2012). Peran Sektor Luar Negeri Pada Perekonomian Indonesia. Majalah Tempo edisi 12-19 November 2012. 